\title{
The Performance Persistence of Equity and Blended Mutual Funds in Kenya
}

\author{
Mohamed Shano Dawe ${ }^{1}$, Ganesh P. Pokhariyal ${ }^{2} \&$ Muroki F. Mwaura ${ }^{3}$ \\ ${ }^{1}$ Meru University of Science and Technology, Kenya \\ ${ }^{2}$ University of Nairobi, Kenya \\ ${ }^{3}$ Williamson Paterson University, Kenya \\ Correspondence: Mohamed Shano Dawe, School of Business and Economics, Meru University of Science and \\ Technology, Meru, Kenya. Tel: 254-720-881-331. E-mail: mohamedsdawe@gmail.com
}

Received: April 8, 2014

Accepted: May 22, 2014

Online Published: July 25, 2014

doi:10.5539/ijef.v6n8p153

URL: http://dx.doi.org/10.5539/ijef.v6n8p153

\begin{abstract}
This paper evaluates the performance persistence of equity and blended mutual funds in Kenya for the period 2006 to 2009. The objective of the study was to establish persistence of funds' performance. The target population was seven mutual funds for which net asset values were available over the period from 1st January 2006 to $31^{\text {st }}$ December 2009. The data was collected from the funds database and annual reports available in the business daily newspapers and in some cases from fund managers' themselves. The data included mutual funds daily returns and annual reports for the period 2005 to 2009 . The data was used to calculate the performance persistence of mutual funds in Kenya.

Performance persistence of mutual funds was analyzed using regression equation developed by Grinblatt and Titman (1993). The general finding was that for both equity and blended fund, there was evidence of performance differences which tend to persist over time. This implies that there is significant performance persistence over the research period and therefore investors can successfully use the measures of past performance as a decision tool for fund selection.
\end{abstract}

Keywords: persistence, mutual funds, NAV

\section{Introduction}

For mutual funds to be successful, professional fund managers should be able to earn above average returns consistently through successful securities analysis. This gives indication to investors which fund to avoid or invest in. However, there is a challenge to pick mispriced securities into the portfolio in order to earn excess return for the investors. The excess return is earned when the individual portfolio has higher return than that of the aggregate market that acts as a benchmark. The magnitude of returns so generated from mutual funds are affected by many factors such as ability of market timing, managerial skills, marketability, liquidity, time horizon, risk, global issues, population, and fund expenses.

Persistence is fund's performance which is consistently above (or below) the average performance for a group of similar funds. Performance analysis will give indication to investors about which fund to avoid or invest in. According to Fletcher and Forbes (2002), there are at least two reasons why performance persistence is an important issue of study. The first is to examine whether fund managers have superior investment skills and a second reason for studying persistence is to consider whether past performance provides information about future performance for investors.

The advantages of mutual funds led to worldwide mutual funds industry to grow significantly during 1990s. This was due to a shift by individual investors from real estate and tangible assets to financial assets, increase of such investors to preferences to indirect ownership of stock and bonds through mutual funds and the growth of tax deferred investing for retirement through pension plans which were used to own mutual funds (Fabbozi \& Modigliani, 2002).

The number of mutual funds grew substantially in the United States of America (USA) from 1980s. At the end of 2005 , the combined assets of U.S. mutual funds approached $\$ 9$ trillion, up from $\$ 370$ billion in 1984 , while the 
number of individual funds grew from 1,200 to almost 9,000 over the same period (Bliss, Potter, and Schwarz, 2008).This reflects that the investing public relies on non-bank financial institutions and increased sophistications of investors in terms of their knowledge of and appreciation of alternatives to commercial bank services (Johnstone, Hatem, \& Carnes 2010).

In Kenya, the mutual fund industry did not take off as early as in developed countries. According to Capital market authority (CMA) investor education handbook (2010), there were eleven unit trusts as at 2010 with an average value of Ksh.17.6 billion. These included African Alliance unit Trust, Old Mutual Unit Trust Scheme, British American Unit Trust Scheme, Stanbic Unit Trust Scheme, Commercial Bank of Africa unit Trust Scheme, Zimele Unit Trust Scheme, Suntra Unit Trust Scheme, Insurance Companies of East Africa (ICEA) Unit Trust Scheme, CFC Unit Trust, Dyer and Blair Unit Trust Scheme and Standard Unit Trust Scheme. The number as at 2010 that was in operation and making the necessary reporting were only eight excluding CFC Unit Trust, Dyer and Blair and Standard Unit Trust.

There were three types of unit trusts in Kenya, namely; equity funds, money market and blended funds. Equity funds have an objective of maximizing returns in the long run. To achieve this, they are fully invested in shares listed on Nairobi Security Exchange (NSE) and selected shares in the regional market. They are diversified across all the sectors of the equity market and are suitable for investors with long-term horizon. Money market and income securities are intended for the stability of the capital. It is invested in treasury bills and short-term bonds. It is also diversified across securities and is ideal for investors with a short-term horizon. Blended fund is a fund invested in both equity and bond and is intended for the stability of both capital and its growth. It is suitable for investors with medium term outlook.

Despite the growth in number of mutual funds, the literature on performance persistence in Kenya is extant. This study therefore seeks to fill this gap by examining the performance persistence in Kenya.

In order to establish the performance persistence of actively managed portfolio's returns overtime, Use of Measures of Persistence (PP) applied by Bers and Mandura (2000) Goetzmann et al. (1994), Blake, Elton, and Gruber (1993) and Grinblatt and Titman (1992) that regresses future performance on the past performance. This study therefore seeks to answer the hypothesis thatMutual fund's past performance is unrelated to future performance.

The following is the theory and the models that underlie performance persistence.

\subsection{Market Efficiency}

Fama (1970) developed Capital Market Theory, as an extension of Portfolio Theory developed by Markowitz (1952). A capital market is either efficient or inefficient. An efficient Capital Market requires that in setting the prices of securities at any time ${ }_{t-1}$, the market correctly uses all available information. Sharpe (1975) argues that in a perfectly efficient market, any attempt to obtain performance superior to that of the overall market portfolio taking into account both risk and return by picking and choosing among securities would fail. That is, security prices fully reflect all available information. Information is therefore, a key issue of the efficient market concept (Jones, 2004). Market therefore, responds very quickly to new information affecting the value of the securities. If trades were made at prices that reflect full information, the market is over efficient, which means, it is so well informed that it cannot compensate the information-gathering function, a clearly unstable condition (Ippolito, 1989).

Malkiel (1995) argues that in an efficient financial market, no investors are allowed to earn above-average returns without accepting above-average risks.

According to efficient market hypothesis, active portfolio management is a wasted effort and unlikely to justify the expenses incurred making it the best strategy. It therefore, makes no attempt to outsmart the market but only aims at establishing a well-diversified portfolio of securities without attempting to find over or under priced stocks (Bodie, Kane, Marcus, \& Mohanty, 2002). The goal of performance measure is to rank managers by the accuracy of their private information on future asset returns. However, this may bring a problem of risk-aversion of the fund manager.

The implication of the theory to this research is that if the market is efficient, no investor can earn abnormal return. The portfolio managers are expected to select a well-diversified portfolio providing the systematic risk level that the investor wants. Therefore, this makes the market timing skills of fund managers a wasted effort.

The research findings on performance persistence are ambiguous. Some studies support persistence while others do not. Sharpe (1966) was one of the earliest studies that documented persistent performance in mutual funds by examining the net return of thirty-four mutual funds and comparing their relative performance, and that of a 
market index concluded that relative performance differences exist, and that this relative performance persists over time.

Grinblatt et al. (1993) used regression analysis by regressing future performance ${ }_{t+1}$ on past performance. They documented weak statistical evidence of persistence in mutual fund risk adjusted returns over five year periods.

Brown and Goetzmann (1995) used a sample that consisted of defunct and surviving funds. They found that relative performance persists for both winners and losers for both raw and risk-adjusted returns, even after controlling for investment objective.

More recently, the studies by Ammann, Huber and Schmid (2010) which used probit regression on merged sample over a period of 1994-2008 found statistically and economically significant performance persistence for time horizons of up to 36 months.

However, the finding by Capocci and Hubner (2004) who used 2796 individual US funds including dissolved 801 funds to investigate hedge funds' performance using various asset-pricing models that indicated limited evidence of persistence in performance even though not for extreme performers.

Further, the study by Prather, Bertin and Henker (2003) provided a comprehensive examination of mutual fund performance by analyzing a large set of both mutual funds and fund attributes in an effort to link performance to fund-specific characteristics. Their results indicate that after controlling for survivorship and benchmark error as well as fund-specific factors, the results refute the performance persistence phenomenon.

In a different study, Jans and Otten (2008) examined the tournaments in the UK mutual Fund industry. They used contingency tables to study the risk-taking behaviour of fund managers of a sample of 422 UK equity mutual funds with monthly data from 1989 to 2003. Managers who trail the market in the first half of the year increase risk to catch up with the market, while managers who are ahead of the market lock in their winner status (commonly referred to as the tournament hypothesis). They found no consistent evidence for tournament behaviour by using the entire 1989-2003 sample period. However, splitting the sample period into two sub-periods reveals significant evidence for tournament behaviour and strategic behaviour.

Recently, Białkowski and Otten (2010) also examined the performance of mutual funds in emerging markets in Poland by using a 4-factor asset-pricing model on survivorship bias controlled sample of 140 funds. Their results suggest that Polish mutual funds on average are not able to add value, as indicated by their negative net alphas and that even past winners are not able to significantly beat the market.

\section{Data and Methodology}

The monthly data pertaining to seven mutual funds for which net asset values were available over the period from 1st January 2006 to 31st December 2009 was collected from the funds database and annual reports available in the business daily newspapers and in some cases from fund managers themselves. The period was chosen because it was the period when the mutual funds in Kenya experienced rapid growth in both the number and the asset value. The Return of 20 NSE share Index was taken to serve as a benchmark for the market portfolio while 91-day Kenya Government Treasury bill was used as a proxy for risk free rates. Since the Treasury bill rate is an annualized holding period return,it is converted to 91 day rate as follows:

$$
i_{T-\text { bill }}(d y) \frac{P_{F}-P_{o}}{P_{F}} x \frac{360}{h},
$$

where:

$i_{\text {T-bill }}=$ Annualized yield on the T-bill;

$P_{F}=$ price (face value) paid to the bill;

$P_{o}=$ Purchase price of the T-bill;

$h=$ Number of days until the T-bill matures;

The monthly return for both the individual funds and the market were calculated using the following equation:

$$
R_{t}=\frac{N A V_{t}-N A V_{t-1}}{N A V_{t}}
$$

Where $R_{t}$ is the monthly individual funds returns for both equity and blended, $N A V_{t}$ is the succeeding net asset value of each fund while $\mathrm{NAV}_{\mathrm{t}-1}$ is the proceeding net asset value for each fund.

The performance persistence for each funds were then calculated using the regression model adopted by Bers and Mandura (2000) and earlier by Goetzmann et al. (1994), Blake et al. (1993) and Grinblatt et al. (1992). 
According to Grinblatt et al. (1992) other models were inappropriate for evaluating the persistence of funds in small markets due to limited sample. Kahn and Rudd also argue that regression and contingency table yield the same result and conclusion. Bers et al. (2000) applied this model on closed ended mutual funds. However, this research applied the model on open-ended funds.

Accordingly, persistence can be tested by comparing the measure of performance (referred to as $\boldsymbol{\alpha}$ over an evaluation period with $\boldsymbol{\alpha}$ over a holding). They divided the testing procedure into three, namely:

i) The total sample of monthly returns is split into two sub-periods (period $1=$ evaluation period, period $2=$ holding period). That is, $t$ is a normal months in a year also referred to as evaluation period while $t-1$ also referred to as holding period is a lagged period

ii) The abnormal returns for each fund were calculated for each sub-period using a multi-index version of Jensen's model (Jensen, 1968), a time-series regression:

$$
r_{i t}={ }_{\alpha_{i}}+\sum_{j=1}^{i} \beta_{i j} r_{i j}+\epsilon_{i t}
$$

where: $\mathbf{r}_{\mathrm{it}}=$ the monthly excess return of fund $\mathrm{i}$ in month $\mathrm{t}$ over the 3-month T-bill rate given by $R_{p}-R_{f}$ for each month; $\boldsymbol{r}_{\beta i j}=$ the monthly excess return of the benchmark $\boldsymbol{j}$ over the T-bill rate at time $\mathrm{t}$ given by Rm-Rf; $\boldsymbol{\beta}_{i j}=$ the sensitivity of fund $i$ 's return to the benchmark $j ; \boldsymbol{\alpha}_{i}=$ a measure of abnormal return (outperformance) for all the windows; and $\boldsymbol{\epsilon}_{i t}=$ the random error term.

The alphas and betas were estimated based on 12-month windows. The windows are then moved one at a time to get the lagged data.

A significantly positive $\alpha$, signifies that the open-end fund $i$ outperformed the benchmarks. Conversely, a significantly negative $\boldsymbol{\alpha}_{i}$ signifies that the mutual fund i underperformed the benchmarks;

iii) Abnormal returns computed from the second period are then regressed on abnormal returns computed from the first period in a cross-sectional regression given by

$$
\alpha_{2 i k}=a+p p_{\alpha l i k}+\varepsilon_{i k}
$$

Where $\alpha_{2 i \mathrm{k}}=$ fund i's alpha for the $\mathrm{k}^{\text {th }}$ holding period (period 2); PP = a measure of persistence; $\alpha_{1 \mathrm{ik}}=$ fund i's alpha for the $\mathrm{k}^{\text {th }}$ evaluation period (period 1); and $\varepsilon_{i k}=$ the error term.

A significant t-statistic for the slope coefficient "PP" in this regression would reject the null hypothesis that past performance is unrelated to future performance and support the alternative hypothesis that past performance is related to future performance. A positive coefficient is evidence for performance persistence and a negative coefficient is evidence of performance reversal.

\section{Empirical Results}

Table 1 below gives a summary of coefficients from the persistence regression for blended funds. Theses regressions are of the form $\mathrm{alpha}_{\mathrm{t}}=\mathrm{a}+\mathrm{pp}$ alpha $\mathrm{t}_{\mathrm{t}-1}+\mathrm{e}_{\mathrm{it}}$ where $\mathrm{a}$ is the intercept/constant term and $\mathrm{pp}$ is a measure of persistence.

Table 1. Performance persistence for blended funds

\begin{tabular}{llllll}
\hline & & Estimate & Std. Error & t value & p-value \\
\hline African Alliance & Intercept 'a' & -0.0086 & 0.0077 & -1.1100 & 0.2790 \\
& 'PP' & 0.8936 & 0.0953 & 9.3797 & $0.0000^{* *}$ \\
Britak & Intercept 'a' & -0.0082 & 0.0045 & -1.8473 & $0.0734^{*}$ \\
& 'PP' & 0.8861 & 0.0659 & 13.4385 & $0.0000^{* *}$ \\
ICEA & Intercept 'a' & -0.0450 & 0.0218 & -2.0649 & $0.0658^{*}$ \\
\multirow{3}{*}{ Dyer and Blair } & 'PP' & 0.3867 & 0.2961 & 1.3060 & 0.2208 \\
\multirow{3}{*}{ OMK } & Intercept 'a' & -0.0395 & 0.0216 & -1.8329 & 0.1165 \\
& 'PP' & 0.2451 & 0.3475 & 0.7055 & 0.5069 \\
Suntra & Intercept 'a' & -0.0079 & 0.0042 & -1.8776 & $0.0690^{*}$ \\
& 'PP' & 0.8974 & 0.0596 & 15.0446 & $0.0000^{* *}$ \\
& Intercept 'a' & -0.0947 & 0.0456 & -2.0776 & $0.0645^{*}$ \\
& 'PP' & 0.0453 & 0.4452 & 0.1017 & 0.9210 \\
& Intercept 'a' & -0.0345 & 0.0146 & -2.3576 & $0.0277^{* *}$ \\
\hline
\end{tabular}

Note. $*$ significant at $90 \%$ level and $* *$ significant at $95 \%$. 
Table 1 above shows the performance persistence denoted as 'PP' for all the blended funds over the period 2006 to 2009. The result indicate that all the funds had positive persistence coefficient. OMK had the highest coefficient of 0.897 , followed by African Alliance with 0.893, Britak with 0.886, Zimele with 0.686, ICEA with 0.386 Dyer and Blair with 0.245 and finally Suntra with 0.043 .

The result indicate that only African Alliance, Britak, OMK and Zimele were significant at 5\% levels of significance as they had a $p$ value less than 0.005 while all the others which included ICEA, Dyer and Blair and Suntra were not significant as they had a $p$ value greater than 0.005 .

As also shown in Table 2 below for equity funds, all the funds had positive persistence coefficient. CBA had the highest coefficient of 0.9354, and then followed by OMK with 0.935, Suntra with 0.913, Britak with 0.835, African Alliance with 0.809 ICEA with 0.642 and finally Dyer and Blair with 0.421.

Table 2. Performance persistence for equity funds

\begin{tabular}{|c|c|c|c|c|c|}
\hline & & Estimate & Std. Error & t value & p-value \\
\hline \multirow[t]{2}{*}{ African Alliance } & Intercept ' $\mathrm{a}$ ' & -0.0172 & 0.0070 & -2.4407 & 0.0232 \\
\hline & 'PP' & 0.8096 & 0.0828 & 9.7750 & $0.0000 * *$ \\
\hline \multirow[t]{2}{*}{ Britak } & Intercept ' $a$ ' & -0.0087 & 0.0050 & -1.7221 & 0.0941 \\
\hline & 'PP' & 0.8350 & 0.0984 & 8.4822 & $0.0000 * *$ \\
\hline \multirow[t]{2}{*}{ CBA } & Intercept ' $\mathrm{a}$ ' & -0.0056 & 0.0039 & -1.4222 & 0.1641 \\
\hline & 'PP' & 0.9354 & 0.0513 & 18.2184 & $0.0000 * *$ \\
\hline \multirow[t]{2}{*}{ DYER AND BLAIR } & Intercept ' $a$ ' & -0.0413 & 0.0358 & -1.1530 & 0.2757 \\
\hline & 'PP' & 0.4219 & 0.4983 & 0.8468 & 0.4169 \\
\hline \multirow[t]{2}{*}{ ICEA } & Intercept ' $a$ ' & -0.0315 & 0.0304 & -1.0357 & 0.3248 \\
\hline & 'PP' & 0.6426 & 0.3262 & 1.9700 & 0.0771 \\
\hline \multirow[t]{2}{*}{ OMK } & Intercept ' $\mathrm{a}$ ' & -0.0056 & 0.0038 & -1.4699 & 0.1508 \\
\hline & 'PP' & 0.9350 & 0.0516 & 18.1269 & $0.0000 * *$ \\
\hline \multirow[t]{2}{*}{ Suntra } & Intercept ' $a$ ' & -0.0050 & 0.0219 & -0.2266 & 0.8253 \\
\hline & 'PP' & 0.9130 & 0.2462 & 3.7088 & $0.0040 * *$ \\
\hline
\end{tabular}

Note. $*$ Significant at $90 \%$ level and $* *$ significant at $95 \%$.

The result indicate that all the funds except ICEA and Dyer and Blair had a significant performance persistence The breakpoint or stability of the performance persistence coefficient were also tested for both equity and blended funds using OLS based CUSUM whose result were as shown in Table 27 below:

Table 3. OLS based CUSUM test for equity and blended funds

\begin{tabular}{lll}
\hline & Test statistic $($ So $)$ & P value \\
\hline Equity & 0.7369 & 0.6492 \\
Blended & 1.4506 & 0.02974 \\
\hline
\end{tabular}

Table 3 above give the result of the null hypothesis of no structural change, that is, the performance persistence coefficients are not stable. The $\mathrm{p}$ values should be zero for the test to be rejected at $5 \%$ levels of significance. The finding indicates that the equity has a $p$ value greater than 0.05 while blended funds had a $p$ value less than one. This implies that we fail to reject the null hypothesis for equity fund and reject for blended fund. The performance persistence coefficients for equity is therefore stable over the research period while the relationship for blended had been changing over the research period.

The general implication is that the fund that performed well this year repeats the same the following year. This is so because generally, out of seven funds, five funds constituting over $71 \%$ had significant performance persistence. Therefore, there is evidence of performance persistence in both equity and blended funds hence rejecting the null hypothesisthat there is no difference in performance for preceding and succeeding period.

The complete fund industry persistence performance as given in Table 3 below also confirms the same findings. 
Table 4. Complete industry fund performance persistence

\begin{tabular}{|c|c|c|c|c|}
\hline \multicolumn{5}{|c|}{ alpha $=\mathrm{a}+$ pp*alpha $(-1)+\mathrm{e}$} \\
\hline & Estimate & Std. Error & $\mathrm{t}$ value & $\operatorname{Pr}(>|t|)$ \\
\hline (Intercept) & 0.00000 & 0.00000 & 4.89362 & 0.00029 \\
\hline Estimate1 & 1.00000 & 0.00000 & \#\#\#\#\#\#\#\# & 0.00000 \\
\hline
\end{tabular}

The persistence data were a panel data, that is, observation of several companies with different time period. The excess returns were obtained by dividing the entire period into sixteen quarters with the first one in 2006 and the last one in 2009. This gave sixteen alphas that were used to obtain the lagged alphas so as to determine coefficient of performance persistence. The alphas were estimated by creating dummy variables for each quarter. The model is estimated by least square dummy variables. The result indicates that the performance persistence is not statistically different from one implying the whole industry is highly persistent.

\section{Discussions of Findings}

This finding is in agreement with that of Amman et al. (2010) which used probit regression on merged sample over a period of 1994-2008 found statistically and economically significant performance persistence for time horizons of up to 36 months. It is also consistent with finding by Polwitoon et al. (2005) who found that the funds exhibit short-run performance persistence, but this is difficult for investors to exploit, especially in the long-run. Global funds show no return seasonality during the sample period.

Similar results were obtained by Agarwal and Yaik (2000), Baquero, Horst, and Verbeek (2005) and Grinblat et al. (1992) who also found that differences in performance persists overtime. More recently, Ammann et al. (2010) used a panel probit regression approach to identify fund characteristics that are significantly related to performance persistence and found statistically and economically significant performance persistence for time horizons of up to 36 months. Also Tonks (2013) most recently found the same results by looking at performance persistence of pension funds in the UK.

Grinblatt and Titman (1993) used regression analysis by regressing future performance ${ }_{t+1}$ on past performance ${ }_{t}$. They documented weak statistical evidence of persistence in mutual fund risk adjusted returns over five year periods.Brown and Goetzmann (1995) used a sample that consisted of defunct and surviving funds. They found that relative performance persists for both winners and losers for both raw and risk-adjusted returns, even after controlling for investment objective.

This study howeveris not consistent with the findings by Blake et al. (2002) that used nonlinear model on bond funds and found no evidence of predictability using past performance to predict future performance. Prather et al. (2004) who also after controlling for survivorship and benchmark error as well as fund-specific factors, the results refute the performance persistence phenomenon and Hujj and Derwall (2006) using 300 bond funds find statistically negative persistence in forward looking alphas. An earlier study by Liow (1997) who studied the historical performance of Singapore property stock indicated that company performing well in one year did not perform well in the next year and also Philpot, Hearth, Rimbey and Schulman (1998) confirms the same findings for bond funds.

As blended fund consist of both equity and bonds, the findings for both equity or bond holds true for blended.

The finding by Capocci et al. (2004) who used 2796 individual US funds including dissolved 801 funds to investigate hedge funds' performance using various asset-pricing models that indicated limited evidence of persistence in performance even though not for extreme performers.

Further, the study by Prather et al. (2003) provided a comprehensive examination of mutual fund performance by analyzing a large set of both mutual funds and fund attributes in an effort to link performance to fund-specific characteristics. Their results indicate that after controlling for survivorship and benchmark error as well as fund-specific factors, the results refute the performance persistence phenomenon.

In a different study, Jans et al. (2008) examined the tournaments in the UK mutual Fund industry. They used contingency Tables to study the risk-taking behaviour of fund managers of a sample of 422 UK equity mutual funds with monthly data from 1989 to 2003. Managers who trail the market in the first half of the year increase risk to catch up with the market, while managers who are ahead of the market lock in their winner status (commonly referred to as the tournament hypothesis). They found no consistent evidence for tournament behaviour by using the entire 1989-2003 sample period. However, splitting the sample period into two sub-periods reveals significant evidence for tournament behaviour and strategic behaviour. 


\section{Conclusions and Recommendations}

The study sought to examine the performance persistence of funds over time. The fund that performed well in one year performed well in the following year. Therefore, past relative performance canenhance an investor's probability of selecting a future winner. In agreement with many other empirical researches, the funds exhibit significant performance persistence. Therefore, there is indication of the fund repeating its good or bad performance in the subsequent years. Investors therefore can successfully use measures of past performance as a decision tool for fund selection.

The study recommends areas that need to be investigated further.The finding that performance was not the indicator of growth requires a further research to establish factors that caused the growth in mutual funds. The study is to be carried out on the effect of recent government regulation of unit trust on its performance, the impact of outreach activities by the funds on its performance and the adoption of county government on the performance of mutual funds in Kenya.

Investors must be mindful of the following caveats while weighing up the empirical evidence: First, the performance measures for the funds in Kenya may have been mainly affected by political factors. The choice of the period fell in 2007 when the country had a general electionsfollowed by post-election violence in 2008 . This may have not given the true performance of the funds as compared to findings by others in other parts of the world.

Secondly, whether a particular fund outperformed the market or not could be attributed to a mere chance. This is because the market is assumed to be efficient implying that all the fund managers can access the same set of information. However, it may be argued that the fund size is likely to be the main factor in influencing the performance due to reduction in cost per unit of the fund due to economies of scale.

Finally, the study sought to establish the performance of mutual funds in Kenya over a five year's period using NSE as a benchmark. Since the Kenya mutual funds are in rapid growth stage, many of them have a short age. There were only two funds which recorded five years of age. This created a bias towards more recentlyestablished mutual funds in the study.

\section{Acknowledgements}

My special thanks go to Gilbert Mbaara for his support in analyzing the data and my wife Nuria Mamo for continuously typing and editing this noble work and not to forget Dr Keneth Waweru for his all manner of support.

\section{References}

Agarwal, V., \& Yaik, N. (2000). Multi-period performance persistence analysis and hedge funds. Journal of Financial and Quantitative Analysis, 35(3), 327-342. http://dx.doi.org/10.2307/2676207

Ammann, M., Huber, O., \& Schimid, M. (2010). Hedge fund characteristics and performance persistence. European Financial Management (Forthcoming). http://dx.doi.org/10.1111/j.1468-036X.2010.00574.x

Bers, M. K., \& Madura, J. (2000). The performance persistence of closed-end funds. Financial Review, 35, 33-52. http://dx.doi.org/10.1111/j.1540-6288.2000.tb01420.x

Bialkowski, J., \& Otten, R. (2011). Emerging market mutual fund performance:Evidence for Poland. North American Journal of Economics and Finance, 22, 118-130. http://dx.doi.org/10.1016/j.najef.2010.11.001

Blake, C. R., Elton, E. J., \& Gruber, M. J. (1994). The performance of bond mutual funds. The Journal of Business, 66(3), 1-38.

BodieZvi, K. A., Marcus, J. A., \& Mohanty, P. (2002). Investment (4th ed.). McGraw-hill.

Bliss, R. T., Potter, M. E., \& Schwarz, C. (2008). Performance Characteristics of Individually-Managed versus Team-Managed Mutual Funds. Journal of Portfolio Management, 34(3), 110-119. http://dx.doi.org/10.3905/jpm.2008.706248

Brown, S. J., \& William, N. G. (1995). Mutual fund styles. Journal of Financial Economics, 43, 373-399. http://dx.doi.org/10.1016/S0304-405X(96)00898-7

Capocci, D., \& Hübner, G. (2004). Analysis of hedge fund performance. Journal of Empirical Finance, 11, 5589. http://dx.doi.org/10.1016/j.jempfin.2002.12.002

CMA. (2010). Investors handbook, Kenya

Fabozzi, \& Modigliani. (2002). Foundations of Financial Markets \& Institutions. Pearson Education. 
Fama, E. F. (1970). Efficient capital markets: a review of theory and empirical work. The Journalof Finance, 25(2), 383-417. http://dx.doi.org/10.2307/2325486

Fletcher, J., \& Forbes, D. (2002). UK unit trust performance: does the benchmark or the measure matter? Journal of Financial Services Research, 21, 195-218.

Grinblatt, M., \& Titman, S. (1993). A study of mutual fund returns and performance evaluation techniques. Journal of Financial and Quantitative Analysis, 29, 419-444.

Huij, J., \& Derwall, J. (2007). Hot hands' in bond funds. Journal of Banking and Finance, 32(2008), 559-572.

Johnston, K., Hatem, J., \& Carnes, T. A. (2010). Investor education: how plan sponsors should report your returns. Managerial Finance, 36(4). 354-363. http://dx.doi.org/10.1108/03074351011027547

Jones, C. P. (2004). Investments: Analysis and Management (9th ed.). New Delhi: John Wiley \& Sons.

Ippolito, R. A. (1989). Efficiency with costly information: a study of mutual fund performance, 1965-1984. The Quarterly Journal of Economics, 104, 1-23. http://dx.doi.org/10.2307/2937832

Kahn, R. N., \& Rudd, A. (1995). Does Historical Performance Predict Future Performance? Financial Analysts Journal, 51(6), 43-52. http://dx.doi.org/10.2469/faj.v51.n6.1948

Liow, K. H. (1997). The historical performance of Singapore property stocks. Journal of Property Finance, 8(2), 111-125. http://dx.doi.org/10.1108/09588689710167816

Malkiel, B. G. (1995). Returns from investing in equity mutual funds from 1971 to 1991. Journal of Finance 50(2), 549-572. http://dx.doi.org/10.1111/j.1540-6261.1995.tb04795.x

Markowitz, H. (1952). Portfolio Selection. Journal of Finance, 7, 77-91.

Philpot, J., Hearth, D., Rimbey, N. J., \& Schulman, T. C. (1998). Active management, fund size, and bond mutual fund returns. The Financial Review, 33, 115-126. http://dx.doi.org/10.1111/j.1540-6288.1998.tb01372.x

Pranther, L., Bertin, W., \& Henker, T. (2004). Mutual fund characteristics, managerial attributes, and fund performance. Review of Financial Economics, 13, 305-326. http://dx.doi.org/10.1016/j.rfe.2003.11.002

Polwitoon, S., \& Tawatnunchai, O. (2006). Diversification benefits and persistence of US-Based global bond funds. Journal of Banking \& Finance, 30, 2767-2786. http://dx.doi.org/10.1016/j.jbankfin.2005.10.003

Sharpe, W. F. (1975). Likely gains from market timing. Financial Analysts Journal, March-April, 60-69. http://dx.doi.org/10.2469/faj.v31.n2.60

Tonks, I. (2005). Performance Persistence of Pension-Fund Managers. The Journal of Business, 78(5), 19171942. http://dx.doi.org/10.1086/431447

Trainor, W. J. (2010). Performance measurement of high yield bond mutual funds. Management Research Review, 33(6), 609-616. http://dx.doi.org/10.1108/01409171011050217

\section{Copyrights}

Copyright for this article is retained by the author(s). with first publication rights granted to the journal.

This is an open-access article distributed under the terms and conditions of the Creative Commons Attribution license (http://creativecommons.org/licenses/by/3.0/). 